\title{
Body Image Anxiety on University Students (Differences between Men and Women)
}

\author{
Humberto Blanco Vega, Juan Francisco Aguirre Chávez, \\ Judith Margarita Rodríguez-Villalobos, José René Blanco Ornelas, \\ Héctor Luis Medina López* \\ Faculty of Physical Culture Sciences, Autonomous University of Chihuahua, Chihuahua, México \\ Email: Lópezhmedina@uach.mx
}

Received 10 August 2014; revised 10 September 2014; accepted 7 October 2014

Copyright (C 2014 by authors and Scientific Research Publishing Inc.

This work is licensed under the Creative Commons Attribution International License (CC BY). http://creativecommons.org/licenses/by/4.0/

c) (i) Open Access

\section{Abstract}

The aim of this research lies on comparing anxiety body image profiles between male and female university students. A total sample of 2089 freshmen -902 women and 1187 men is from the different degrees offered by the Autonomous University of Chihuahua, with an average age of $18.23 \pm$ 0.74 years. The approach used in the research is part of a quantitative design with a survey description. The differences found between men and women regarding their own perception of anxiety suggest that when designing any kind of intervention that aims at the decreasingly perceived anxiety, the gender variable will have to be taken into account. Future investigations should respond to these discoveries in larger samples.

\section{Keywords}

Students' Beliefs, Gender Differences, Higher Education, Academic Performance, Students' Characteristics

\section{Introduction}

The ideal thin weight and worries about weight come from a cultural idea that even nowadays is considered esthetic. It is just a fashion and it is not necessarily healthy or accessible, which may have negative consequences that generate anxiety such as a great worry about weight and having good physical shape which can be shown as body dissatisfaction that reveals how individuals value or despise their own bodies, and/or their body distortion, which is the lack of precision in determining the body size [1].

The body image and the esthetic norms that actually rule the occidental world can affect the physiological

"Corresponding author.

How to cite this paper: Vega, H.B., Chávez, J.F.A., Rodríguez-Villalobos, J.M., Ornelas, J.R.B. and López, H.L.M. (2014) Body Image Anxiety on University Students (Differences between Men and Women). Open Journal of Medical Psychology, 3, 348354. http://dx.doi.org/10.4236/ojmp.2014.35036 
development of men as well as of women. But pre-adolescent and adolescent women present a higher tendency on having problems of the body image elaboration linked to development problems on alimentary behaviors [2] [3], because the previous information "beauty and thinness" standards are especially strict for them [4].

Reference [5] says that in a society that glorifies beauty it is not strange that youth and health increase the concern of physical appearance. In fact every year millions of pesos are spent on improving physical appearance. But excessive worry may be highly perturbing and even incapacitating for a lot of people.

Most of the investigators [6]-[10] on alimentary behavior disorders, agree that these come from several unplanned situations, highlighting the worry for body shape and getting on diets, but most of all losing weight, which are considered risky by specialists [7] [8] [11].

Our investigation is supported by the study of anxiety from a psychologist point of view, through the usage of measurement tools suitable to this area and applied to clinically normal population, in order to know their anxiety, state and characteristic levels on their body image [12] through the application of a self-report instrument that allows to identify the anxiety generally present in people's body areas that have to do with their weight, for example, hips, belly and waist, as well as in areas related to physical beauty that don't have to do with their weight, such as the nose, ears and hands that generate evidences and data that promote an educative intervention within an observing perspective on the classroom diversity.

This research is basically a descriptive study that tries to compare the anxiety profiles of the body image perception on male and female university students, taking into account that in the last years body image has taken a huge peak on modern societies, a lot of which have created a subculture based on the perception and importance of an ideal image [13].

\section{Methodology}

\subsection{Participants}

The sample corresponds to 2089 individuals, 902 women and 1187 men, all of them students from the degrees offered by the UACH; using an advantage sampling trying to cover the different degrees representation (Table 1). Ages fluctuate between 17 and 20 years old with a mean of $18.23 \pm 0.74$.

\subsection{Instrument}

The Body Image Anxiety Scale (BIAS) in its original version is a questionnaire of 15 items that evaluates characteristic-anxiety related to weight ( 8 items, Weight Factor) and body areas not related to weight ( 7 items, No Weight Factor) in which the interviewed answers how anxious, stressed or nervous feels regarding these body areas within a scale from 0 to 4 . According to [12], the BIAS has a good inner and temporary stability as well as validity. This type of survey was chosen since it is easy to apply [14]; besides it provides a good base to order the individuals according to the characteristic that it's being measured.

The BIAS version was used in our study, adapted by [15] who, according to their study on university students, made 3 adaptations to the original version:

Table 1. Distribution of the participants according to degree and gender variables.

\begin{tabular}{cccc}
\hline & \multicolumn{2}{c}{ Gender } \\
\hline Discipline & Female & Male & Total \\
\hline Physical Education & 81 & 214 & 295 \\
Humanity and Education & 96 & 72 & 168 \\
Health Sciences & 121 & 108 & 229 \\
Administrative and Social Sciences & 176 & 124 & 300 \\
Political Sciences & 200 & 89 & 289 \\
Engeneering and Technology & 143 & 449 & 592 \\
Agriculture and Livestock Sciences & 85 & 131 & 216 \\
\hline
\end{tabular}


The first one is that the original version uses a 0 to 4 scale, and in the [15] adapted version the individuals chose between eleven possible answers, nothing (0), lightly (1,2 and 3), moderately (4, 5 and 6), a lot (7, 8 and 9) and too much (10) this first adaptation is justified in relation to a 0 to 10 scale of which the individuals are used to, considering that they have been evaluated by our country's (Mexico) educative system, for example, [16] report a similar change on the validation of a scale with similar characteristics on Spanish population [17] with Mexican university students.

For the second adaptation, according to Ornelas' study results (in press), four items from the original version were removed (body weight, muscle tone, eras and feet), and one item was added instead (neck); having 12 items left instead of the 15 from the original version.

The third and last adaptation consisted on applying the instrument on a computer in order to storage the data with no previous codification phases with a higher precision and rapidity.

\subsection{Explanatory Variable}

Gender: male and female.

\subsection{Variable Answers}

Feature Anxiety Weight Factor. The no situational anxiety referred to the individual's weight is estimated based on the score gotten on the first 6 possible answers (thighs, buttock, hips, belly, legs and waist) from the Body Image Anxiety Scale instruments adapted by Ornelas and team members.

Feature Anxiety No Weight Factor. The no situational anxiety referred to the lips, wrists, hands, forehead, neck and chin; is estimated based on the score gotten on the last 6 possible answers from the Body Image Anxiety Scale instrument adapted by Ornelas and team members.

\subsection{Procedure}

All freshmen students from the degrees offered by the UACH were invited to participate; the ones who accepted, signed a corresponding approval letter (informed consent). After this, the instrument previously described was applied on a personal computer using the administrator module of the scale's editor from the instrument, version 2.0 [18] in approximately 25 minutes session; on the computer labs from the academic units that participated on the process. At the beginning of each session there was an introduction about the importance of the research and about how to access to the instrument; the instructions of how to respond were on the first screens; before the first possible answers of the instrument. At the end of the session it was expressed the gratitude for their participation.

Once the instrument was applied, all the results were compiled by the results generator module of the scales' editor version 2.0 [18].

\subsection{Data Analysis}

The analysis variance between groups was used to compare the obtained results by men and women, after proving that the data accomplish with the normality statistics criteria (Shapiro-Wilks test) and for the men and women subsamples was used an analysis variance of repeated means.

An alpha level of 5.0 was used for all of the statistics tests.

\section{Results}

\subsection{Weight and No-Weight Factor Anxiety According to Gender}

According to the results, women are the ones who present higher anxiety on body areas related with weight $\mathrm{F}$ $(1,2087)=156.702, \mathrm{p}<0.001$; while men experience higher levels of anxiety on body areas related with beauty $\mathrm{F}(1,2087)=32.175, \mathrm{p}<0.001$ (Figure 1).

\subsection{Body Areas' Anxiety Related to Weight According to Gender}

According to the results, women are perceived significantly with a higher anxiety on the six body areas studied: 
thighs, $\mathrm{F}(1,2087)=21.286, \mathrm{p}<0.001$; buttocks, $\mathrm{F}(1,2087)=78.906, \mathrm{p}<0.001$; hips, $\mathrm{F}(1,2087)=210.348, \mathrm{p}<$ 0.001 ; belly, $\mathrm{F}(1,2087)=95.046, \mathrm{p}<0.001$; legs, $\mathrm{F}(1,2087)=47.100, \mathrm{p}<0.001$; and waist, $\mathrm{F}(1,2087)=$ 267.713, $\mathrm{p}<0.001$ (Figure 2).

\subsection{Body Areas' Anxiety Related to Beauty (No-Weight Factor) According to Gender}

According to the results, men perceive themselves considerably with higher anxiety on 5 out of 6 body areas studied: lips, $\mathrm{F}(1,2087)=28.674, \mathrm{p}<0.001$; wrists, $\mathrm{F}(1,2087)=62.945, \mathrm{p}<0.001$; forehead, $\mathrm{F}(1,2087)=$ $10.507, \mathrm{p}<0.01$; neck, $\mathrm{F}(1,2087)=19.596, \mathrm{p}<0.001$; and chin, $\mathrm{F}(1,2087)=36.113, \mathrm{p}<0.001$; and without any difference on hands, $\mathrm{F}(1,2087)=3.174, \mathrm{p}>0.05$ (Figure 3 ).

\subsection{Body Areas' Anxiety Related to Weight (Women Subsample)}

The results obtained from the variance analysis of repeated measures for the body areas related with weight $\mathrm{F}$ $(5,4505)=144.924, \mathrm{p}<0.001$ show that belly and waist are body areas related with weight that cause higher anxiety on women; and the hips area causes them less anxiety (Figure 2).

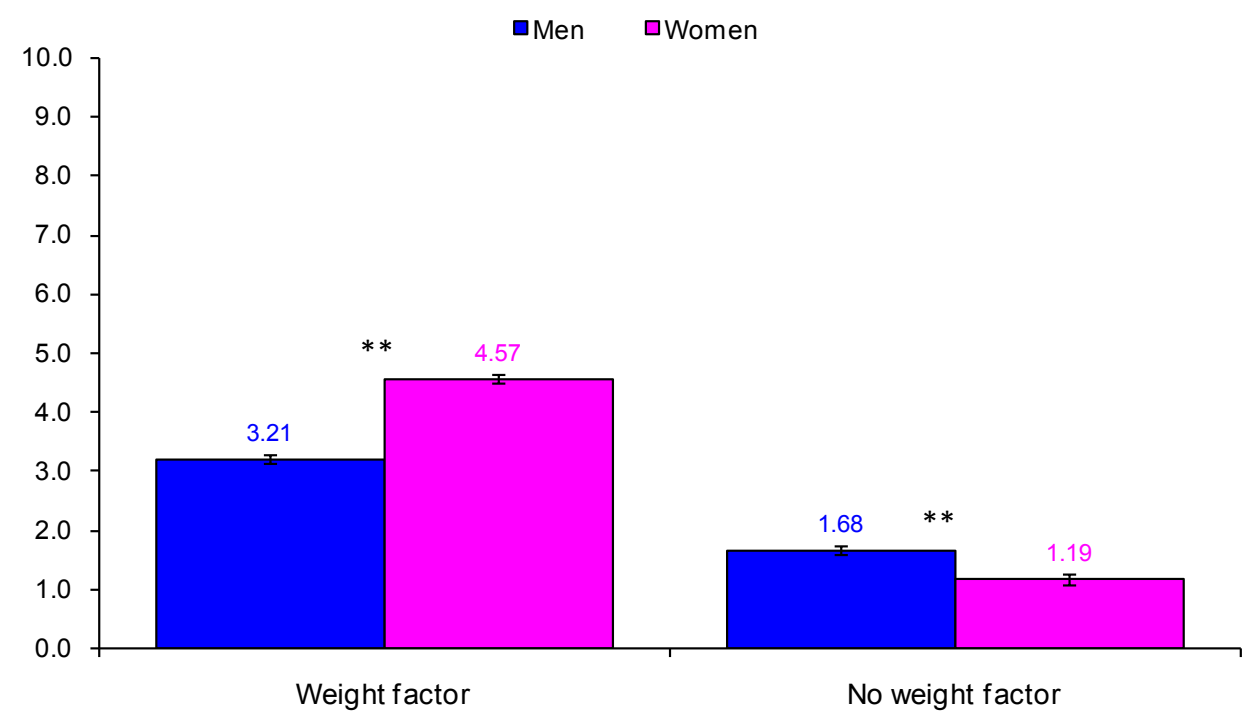

Figure 1. Average of perceived anxiety on each factor according to gender. **Significant differences; $\mathrm{p}<0.01$.

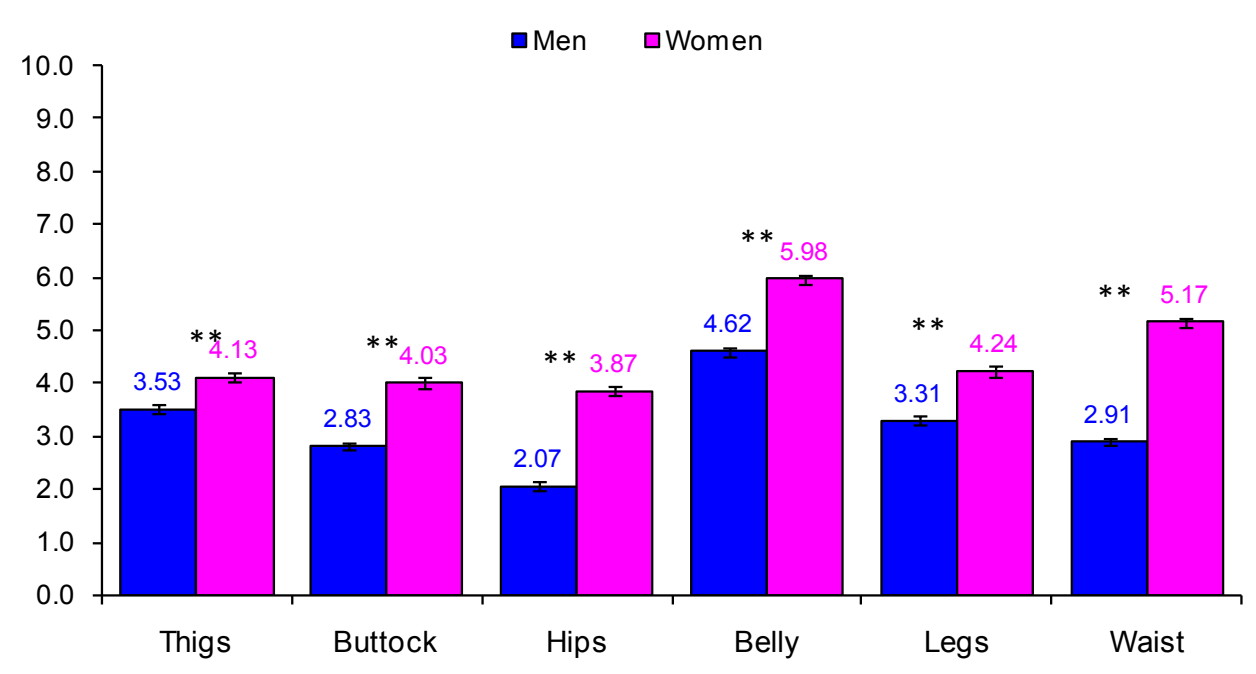

Figure 2. Perceived anxiety average on each of the areas related to weight according to gender. **Significant differences; $\mathrm{p}<0.01$. 


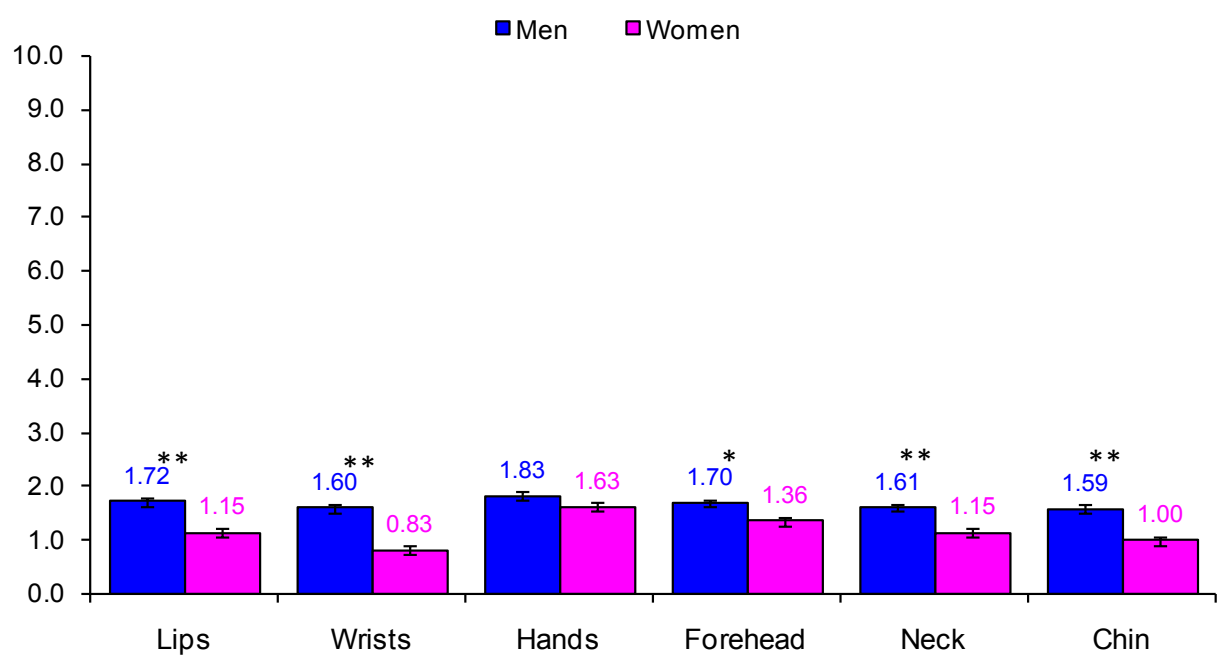

Figure 3. Perceived anxiety average on each of the areas related to beauty according gender. *Significant differences; $\mathrm{p}<0.05 ; * *$ Significant differences; $\mathrm{p}<0.01$.

\subsection{Body Areas' Anxiety Related to Weight (Men Subsample)}

The variance analysis results of repeated measures for body areas related with weight $F(5,5930)=258.449, \mathrm{p}<$ 0.001 show that belly, thighs and legs are body areas related with weight that cause higher anxiety on men; and the hips area is the one that causes them less anxiety (Figure 2).

\subsection{Body Areas' Anxiety Related to Beauty (Women Subsample)}

The variance analysis results of repeated measures for body areas related with beauty $F(5,4505)=33.912, p<$ 0.001 show that hands, lips and forehead are body areas related with beauty that cause higher anxiety on women; and the wrists are is the one that causes them less anxiety (Figure 3).

\subsection{Body Areas' Anxiety Related to Beauty (Men Subsample)}

The variance analysis results of repeated measures for body areas related with beauty $\mathrm{F}(5,5930)=4.906, \mathrm{p}<$ 0.001 show that hands, lips and forehead are body areas related with beauty that cause higher anxiety in men; and the areas that cause them less anxiety are chin, writs, and neck (Figure 3).

\section{Discussion}

Women show higher anxiety related to weight, these results coincide to what [3] [19] mention, they affirm that even nowadays men as well as women are being affected by the socially imposed esthetic archetype and it's problematic. Young women are highly impacted; [20] say that what it was previously mention is thanks to the social "beauty and thinness" standards which are especially strict for them. With the maximum standard being "to be beautiful is equal to being thin", these young women are exposed to see thinner and taller models every time [9] [12].

On the other hand, on the perceived anxiety on body areas related with beauty, men experience higher levels of anxiety; this seems to indicate that being more comfortable with their weight, they focus their attention to body elements of beauty that has to do with the idea of some authors [3] [19] in the sense that nowadays men tend to be more worried about their physical beauty, and besides it can be related with the metro-sexuality phenomena. For example, and continuing with this idea, on a market research about metro sexuality done by [21], it was found that $44 \%$ of the men interviewed are willing to make themselves a surgery in order to improve their appearance.

\section{Conclusions}

In summary, this study provides evidence that the differences found between men and women according to their 
anxiety perception suggest that at designing any type of intervention that has as goal the improvement of this aspect it will have to be taken into account the gender variable. Besides the importance of doing a higher number of investigations about this topic is highlighted in our country since almost all studies about this have been made in foreign countries.

Therefore, the task of decreasing the anxiety on students is a valuable educational goal, under an imaginary condition, reduction will help as means to improve different results such as academic achievements and self-esteem.

\section{Limitations}

Conditions in which the questionnaire was administered could have also been a hindrance to our study. Interviewed on a school day, the subjects were concerned about the confidentiality of their responses.

\section{Acknowledgements}

This study is part of a project funded by the Secretaría de Educación Pública-Subsecretaría de Educación SuperiorDirección General de Educación Superior Universitaria de México [Mexican Ministry of Education-Department of Higher Education-General Directorate of the University Education] (OF-13-6894). Additionally, the fourth author is supported by a grant from the National Council of Science and Technology of Mexico (Conacyt).

\section{References}

[1] Anuel, A., Bracho, A., Brito, N., Rondón, J.E. and Sulbarán, D. (2012) Cognitive Mechanisms of Self-Acceptance and Body Image. Psicothema, 24, 390-395. [Anuel, A., Bracho, A., Brito, N., Rondón, J.E. and Sulbarán, D. (2012) Autoaceptación y mecanismos cognitivos sobre la imagen corporal. Psicothema, 24, 390-395.]

[2] Francisco, R., Alarcão, M. and Narciso, I. (2011) Assessment of Risk of Developing Eating Disorders Factors: Development and Validation Studies of the Portuguese Version of the McKnight Risk Factor Survey IV. Iberoamerican Journal of Psychological Assessment and Diagnosis, 32, 143-170. [Francisco, R., Alarcão, M. and Narciso, I. (2011) Avaliação de factores de risco de desenvolvimento de perturbações alimentares: Desenvolvimento e estudos de validação da versão portuguesa do McKnight Risk Factor Survey IV. Revista Iberoamericana de Diagnóstico y Evaluación Psicológica, 32, 143-170.]

[3] Thompson, J.K. (2003) Introduction: Body Image, Eating Disorders, and Obesity-An Emerging Synthesis. In: Thompson, J.K., Ed., Body Image, Eating Disorders, and Obesity: An Integrative Guide for Assessment and Treatment, American Psychological Association, Washington DC, 1-20.

[4] Calaf, M., León, M., Hilerio, C. and Rodriguez, J. (2005) Inventory Body Image for Teens Féminas (IICFA). Interamerican Journal of Psychology, 39, 347-354. [Calaf, M., León, M., Hilerio, C. and Rodriguez, J. (2005) Inventario de Imagen Corporal para Féminas Adolescentes (IICFA). Revista Interamericana de Psicología, 39, 347-354.]

[5] Raich, R.M. (2004) A Perspective from the Health Psychology of Body Image. Revista Latinoamericana Advances in Psychology, 22, 15-27. [Raich, R.M. (2004) Una perspectiva desde la psicología de la salud de la imagen corporal. Revista Avances en Psicología Latinoamericana, 22, 15-27.]

[6] Goñi, A. and Rodríguez, A. (2007) Variables Associated with the Risk for Eating Disorders in Adolescence. Salud Mental, 30, 16-23.

[7] Inglés, C.J., Piqueras, J.A., García-Fernández, J.M., García-López, L.J., Delgado, B., et al. (2010) Gender and Age Differences in Cognitive, Psychophysiological and Motor Responses of Social Anxiety in Adolescence. Psicothema, 22, 376-381. [Inglés, C.J., Piqueras, J.A., García-Fernández, J.M., García-López, L.J., Delgado, B., et al. (2010) Diferencias de género y edad en respuestas cognitivas, psicofisiológicas y motoras de ansiedad social en la adolescencia. Psicothema, 22, 376-381.]

[8] Lameiras, M., Calado, M., Rodríguez, Y. and Fernández, M. (2003) Dietary Habits and Body Image among College Students without Eating Disorders. International Journal of Clinical and Health Psychology, 3, 23-33. [Lameiras, M., Calado, M., Rodríguez, Y. and Fernández, M. (2003) Hábitos alimentarios e imagen corporal en estudiantes universitarios sin trastornos alimentarios. Revista Internacional de Psicología Clínica y de la Salud, 3, 23-33.]

[9] Solano, N. and Cano, A. (2012) Anxiety in Eating Disorders: A Comparative Study. Psicothema, 24, 384-389. [Solano, N. and Cano, A. (2012) Ansiedad en los trastornos alimentarios: Un estudio comparativo. Psicothema, 24, 384-389.]

[10] Wardle, J., Haase, A. and Steptoe, A. (2006) Body Image and Weight Control in Young Adults: International Comparisons in University Students from 22 Countries. International Journal of Obesity, 30, 644-651.

http://dx.doi.org/10.1038/sj.ijo.0803050

[11] Castillo, B. (2006) Consumer Society and Disordered Eating Behavior. Eating Disorders Conduct, 4, 321-335. 
[Castillo, B. (2006) Sociedad de consumo y trastornos de la conducta alimentaria. Trastornos de la Conducta Alimentaria, 4, 321-335.]

[12] Raich, R.M. (2000) Body Image: Know and Value the Body Itself. Pirámide, Madrid. [Raich, R.M. (2000) Imagen corporal: Conocer y valorar el propio cuerpo. Pirámide, Madrid.]

[13] Banfield, S. and McCabe, M.P. (2002) An Evaluation of the Construct of Body Image. Adolescence, 37, $373-393$.

[14] Raviolo, A., Ramirez, P., López, E.A. and Aguilar, A. (2010) Conceptions of Knowledge and Scientific Models: A Preliminary Study. University Training, 3, 29-36. [Raviolo, A., Ramirez, P., López, E.A. and Aguilar, A. (2010) Concepciones sobre el conocimiento y los modelos científicos: Un estudio preliminar. Formación Universitaria, 3, 29-36.]

[15] Ornelas, M., Blanco, H., Gastélum, G. and Chávez, A. (2014) Psychometric Tests Body Image Test Anxiety Scale for Tertiary Students Feature Version. Educational Profiles, 36, 120-137. [Ornelas, M., Blanco, H., Gastélum, G. and Chávez, A. (2014) Análisis psicométrico de la prueba Body Image Anxiety Scale en alumnos de educación superior versión rasgo. Perfiles Educativos, 36, 120-137.]

[16] Viciana, J., Cervelló, E.M. and Ramírez-Lechuga, J. (2007) Effects of Manipulating Positive and Negative Feedback on Goal Orientation, Perceived Motivational Climate, Satisfaction, Task Choice, Perception of Ability, and Attitude to Physical Education Lessons. Perceptual and Motor Skills, 105, 67-82. http://dx.doi.org/10.2466/pms.105.1.67-82

[17] Blanco, H., Martínez, M., Zueck, M.D.C. and Gastélum, G. (2011) Psychometric Analysis of Academic Self-Efficacy Scale Behaviors in College Freshmen. Investigative News in Education, 11, 1-27. [Blanco, H., Martínez, M., Zueck, M.D.C. and Gastélum, G. (2011) Análisis psicométrico de la escala autoeficacia en conductas académicas en universitarios de primer ingreso. Actualidades Investigativas en Educación, 11, 1-27.]

[18] Blanco, H., Ornelas, M., Tristán, J.L., Cocca, A., Mayorga-Vega, D., López-Walle, J. and Viciana, J. (2013) Editor for Creating and Applying Computerise Surveys. Procedia-Social and Behavioral Sciences, 106, 935-940. http://dx.doi.org/10.1016/j.sbspro.2013.12.105

[19] Facchini, M. (2006) The Preoccupation with Weight and Body Shape in the Current Adolescent Girls: Where Does It Come from? Argentina Journal of Pediatrics, 104, 345-350. [Facchini, M. (2006) La preocupación por el peso y la figura corporal en las niñas adolescentes actuales: ¿de dónde proviene? Revista Argentina de Pediatría, 104, 345-350.]

[20] Dolan, B. and Gitzinger, I. (1994) Why Women? Gender Issues and Eating Disorders. Athlone Press, London.

[21] Zapata, J.A. (2008) Impact of Metrosexual Market Chihuahuan Society. Journal of Research Simiya, 1, 24-28. [Zapata, J.A. (2008) Impacto del mercado metrosexual en la sociedad chihuahuense. Revista de Investigación Simiyá, 1, 24-28.] 
Scientific Research Publishing (SCIRP) is one of the largest Open Access journal publishers. It is currently publishing more than 200 open access, online, peer-reviewed journals covering a wide range of academic disciplines. SCIRP serves the worldwide academic communities and contributes to the progress and application of science with its publication.

Other selected journals from SCIRP are listed as below. Submit your manuscript to us via either submit@scirp.org or Online Submission Portal.
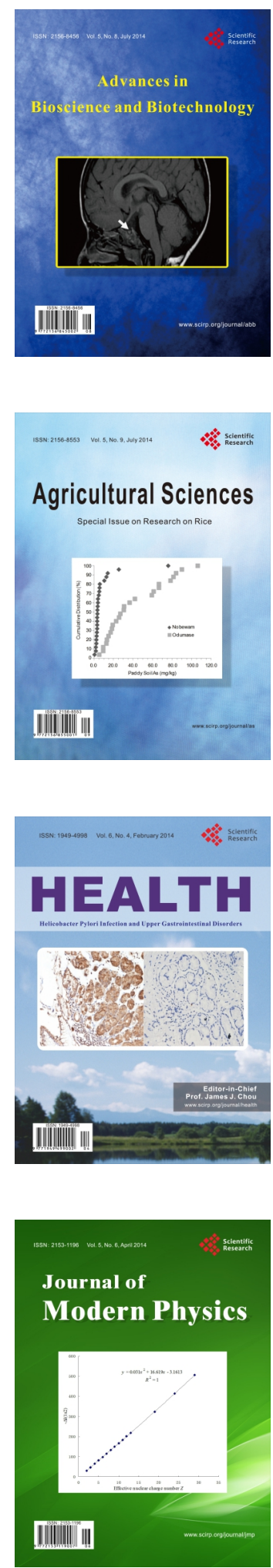
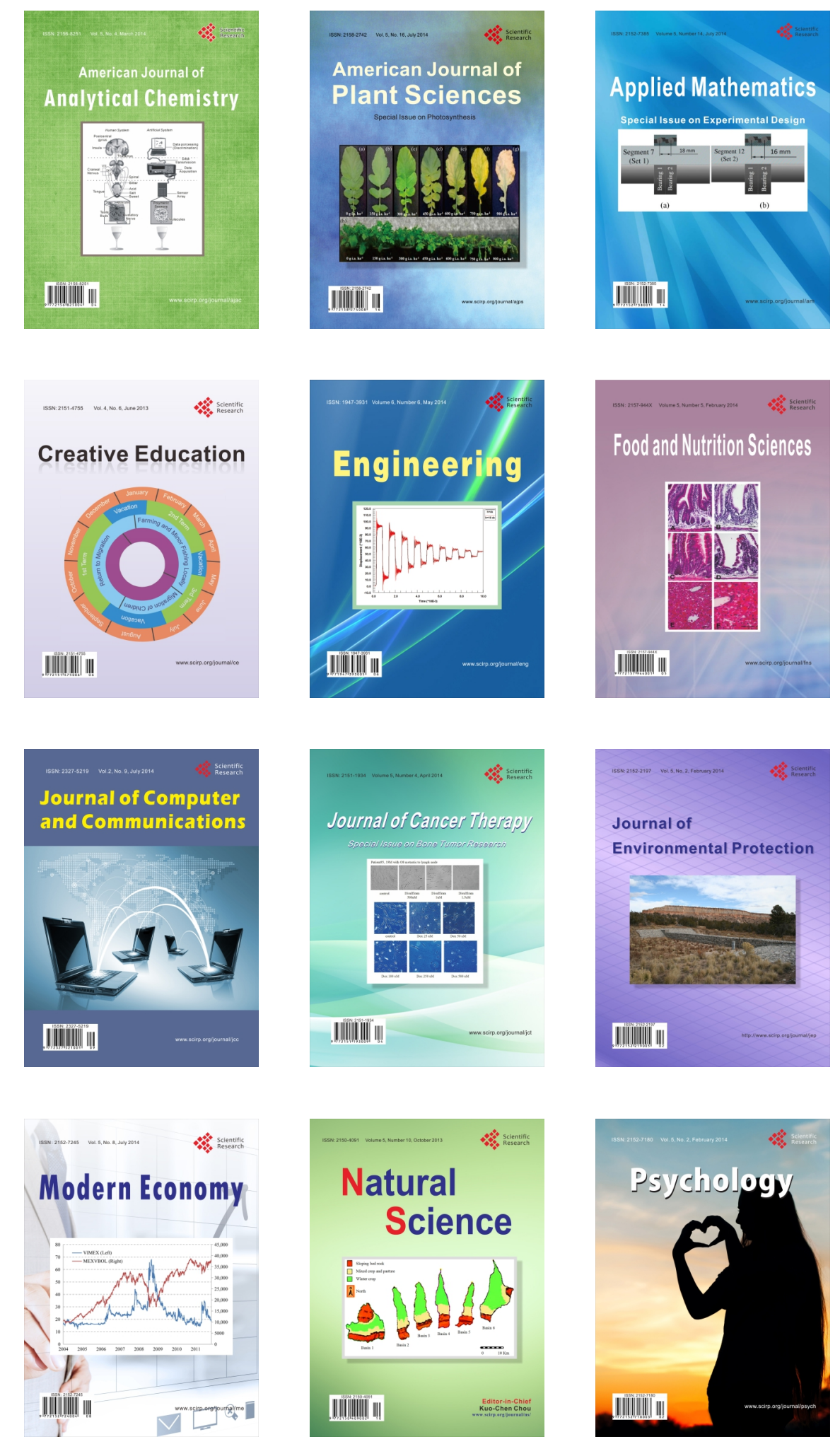